\title{
Stable isotope variation in loggerhead turtles reveals Pacific-Atlantic oceanographic differences
}

\author{
Mariela Pajuelo ${ }^{1, *}$, Karen A. Bjorndal ${ }^{1}$, Joanna Alfaro-Shigueto ${ }^{2,3}$, \\ Jeffrey A. Seminoff ${ }^{4}$, Jeffrey C. Mangel ${ }^{2,3}$, Alan B. Bolten ${ }^{1}$
}

\author{
${ }^{1}$ Archie Carr Center for Sea Turtle Research, Department of Biology, University of Florida, Gainesville, Florida 32611, USA \\ ${ }^{2}$ Pro Delphinus, Octavio Bernal 572-5, Lima 11, Peru \\ ${ }^{3}$ Centre for Ecology and Conservation, School of Biosciences, University of Exeter, Cornwall Campus, Penryn, \\ Cornwall TR10 9EZ, UK
}

${ }^{4}$ NOAA-National Marine Fisheries Service, Southwest Fisheries Science Center, 8604 La Jolla Shores Drive, La Jolla, California 92037, USA

\begin{abstract}
Denitrification and nitrogen-fixation processes in the marine environment have been intensively studied, particularly how these processes affect the nitrogen stable-isotope signature $\left(\delta^{15} \mathrm{~N}\right)$ of inorganic nutrients and organisms at the base of the food web. However, the assumption that these $\delta^{15} \mathrm{~N}$ differences at the base of food webs are reflected in higher trophic-level organisms has not been widely investigated. In the present study, we evaluated whether an ocean-basin $\delta^{15} \mathrm{~N}$ variation was evident in oceanic juvenile loggerhead turtles Caretta caretta by analyzing their stable-isotope signatures in the Pacific and Atlantic oceans. Skin samples from oceanic juvenile loggerheads were collected from Peruvian waters in the southeast Pacific and from waters around the Azores Archipelago in the northeast Atlantic and analyzed for $\delta^{15} \mathrm{~N}$ and carbon stable-isotope signature $\left(\delta^{13} \mathrm{C}\right)$. Our results showed that turtles in the 2 ocean regions have mean $\delta^{13} \mathrm{C}$ signatures of -16.3 and $-16.7 \%$, which reflects the oceanic feeding behavior of these loggerhead populations. However, the $\delta^{15} \mathrm{~N}$ signatures in Pacific loggerheads are significantly higher (mean \pm SD $=17.1 \pm 0.9 \%$ ) than those of Atlantic loggerheads $\left(7.6 \pm 0.5 \%\right.$ ). This inter-ocean difference in $\delta^{15} \mathrm{~N}$ values was also observed in organisms at the base of the food web in the 2 study areas. The $\delta^{15} \mathrm{~N}$ at the base of the food web, which is determined by the predominant process of the nitrogen cycle in each ocean region, is subsequently transferred to higher trophic levels. Stable isotope signatures in high trophic-level organisms, such as oceanic-stage sea turtles, can reveal differences in oceanographic processes.
\end{abstract}

KEY WORDS: Stable isotopes $\cdot \delta^{15} \mathrm{~N} \cdot \delta^{13} \mathrm{C} \cdot$ Loggerhead turtles $\cdot$ Nitrogen fixation $\cdot$ Denitrification $\cdot$ Southeast Pacific $\cdot$ Northeast Atlantic

Resale or republication not permitted without written consent of the publishe

\section{INTRODUCTION}

Nitrogen fixation and denitrification are the 2 main processes by which nitrogen flows into and out of the ocean, respectively (our Fig. 1; Gruber \& Sarmiento 1997, Codispoti et al. 2001, Deutsch et al. 2007). Geographic variation in the abundance ratio ${ }^{15} \mathrm{~N}:{ }^{14} \mathrm{~N}$ (expressed as $\delta^{15} \mathrm{~N}$ ) in marine environments has been explained by distinctive characteristics of the nitrogen cycling in those areas. Low $\delta^{15} \mathrm{~N}$ values in food-web baseline signatures and nitrogen pools provide evi- dence for nitrogen fixation (our Fig. 1a; Minagawa \& Wada 1986, Liu et al. 1996, Carpenter et al. 1997, Montoya et al. 2002), which has been observed in the East China, Sargasso, and Arabian seas, and the western North Atlantic (Minagawa \& Wada 1986, Gruber \& Sarmiento 1997). On the other hand, denitrification evidenced by high $\delta^{15} \mathrm{~N}$ values in inorganic nitrogen, particulate organic matter (POM), and zooplankton (Wada \& Hattori 1976, Saino \& Hattori 1987, Wu et al. 1997, Vos et al. 2001) has been observed in oxygendepleted areas in the eastern tropical North and South 

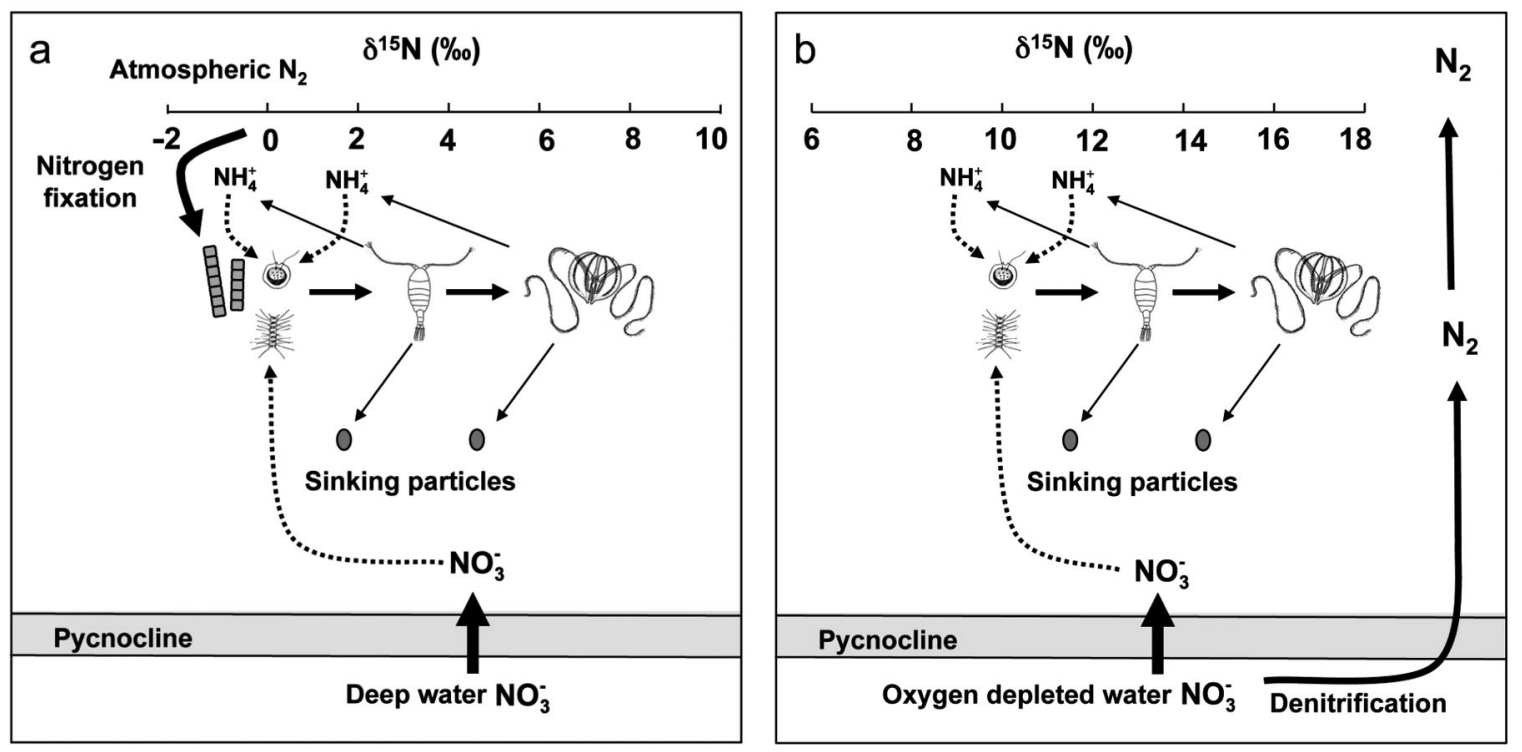

Fig. 1. Schematic $\delta^{15} \mathrm{~N}$ signatures in the upper water column in the presence of (a) $\mathrm{N}_{2}$ fixation and (b) denitrification. Other processes controlling the isotopic signature are also shown. Heavy solid arrows represent inputs of nitrogen at the water surface through nitrogen fixation or upwelled nitrates $\left(\mathrm{NO}_{3}{ }^{-}\right)$. Medium solid arrows represent trophic transfer of nitrogen up the trophic web, and light solid arrows represent losses of ingested nitrogen through solid (sinking particles) and dissolved excreta. Uptake of inorganic nitrogen by primary producers is shown by dashed lines (modified from Montoya 2007)

Pacific, and the Arabian Sea (Gruber \& Sarmiento 1997, Deutsch et al. 2007). Even though these differences in $\delta^{15} \mathrm{~N}$ at the base of the food web in marine systems have been addressed, few have suggested that these baseline differences in $\delta^{15} \mathrm{~N}$ are conserved up the food web (Minami \& Ogi 1997, Takai et al. 2000, Hatase et al. 2002, Wallace et al. 2006).

Stable-isotope analysis is an increasingly widespread approach to elucidate diet, trophic status, foraging habitat, and migration patterns in marine animals (Hobson et al. 1994, Rubenstein \& Hobson 2004). Stable isotopes can be used to address these questions because the tissues of consumers exhibit an enrichment over their diet of about 3 to $5 \%$ for $\delta^{15} \mathrm{~N}$ and 0 to $1 \%$ for $\delta^{13} \mathrm{C}$ (DeNiro \& Epstein 1978, 1981, Minagawa $\&$ Wada 1984). However, these commonly used values can be quite variable (reviewed by Martínez del Rio et al. 2009). Within a biological community, enrichment in $\delta^{15} \mathrm{~N}$ with increasing trophic level is useful for inferring the trophic status of an animal (Hobson et al. 1994, Post 2002). In marine ecosystems, $\delta^{13} \mathrm{C}$ is useful for determining habitat use along 3 gradients: lower versus higher latitude, inshore (neritic) versus offshore (oceanic), or pelagic versus benthic (Rau et al. 1982, Hobson et al. 1994).

Endangered loggerhead turtles Caretta caretta are considered generalist carnivores among sea-turtle species (Bjorndal 1997). Recent analysis of diet in oceanic juvenile loggerheads in the central North
Pacific and the northeast Atlantic revealed that these turtles are pelagic feeders, foraging opportunistically on pelagic gastropods and barnacles, and cnidarians (Parker et al. 2005, Frick et al. 2009). These studies utilized stomach contents, which provided valuable species information on what turtles were ingesting at a particular point of time. Stable-isotope analysis provides a complementary tool to address dietary questions because it quantifies diet over extended periods of time (Hobson et al. 1994, Vander Zanden et al. 2010). The trophic status of a generalist carnivore in known areas of nitrogen fixation or denitrification can provide a broader insight on how these oceanographic processes affect higher trophic levels.

Wallace et al. (2006) showed that leatherback turtles Dermochelys coriacea from the Pacific and Atlantic oceans had significantly different nitrogen isotopic signatures. Those authors (op.cit.) suggested that nitrogen isotopic differences reflected denitrification and nitrogen-fixation processes affecting higher trophic levels. Other studies have reported similar isotopic results on conspecific species inhabiting different oceanographic areas (Minami \& Ogi 1997, Ishibashi et al. 2000, Takai et al. 2000), but none of these included any food-web sampling or at least sufficient food-web sampling to corroborate this observation.

Building on the study of Wallace et al. (2006), we evaluated whether the previously described trophic dichotomy in Pacific and Atlantic Ocean basins was 
evident among other higher-trophic organisms and sought to validate the assumption that differences in the baseline $\delta^{15} \mathrm{~N}$ signatures are preserved throughout the food web. We analyzed the stable isotope ratios $\left(\delta^{13} \mathrm{C}\right.$ and $\left.\delta^{15} \mathrm{~N}\right)$ of juvenile loggerhead turtles, the base of the food web, and other food-web components in 1 area of the Pacific and Atlantic oceans with evidence of prevalence of denitrification and nitrogen-fixation processes, respectively. We also provide insights on the trophic status of juvenile loggerhead turtles as revealed by stable-isotope analysis.

\section{MATERIALS AND METHODS}

Data and sample collection. Loggerhead turtle data were collected off southern Peru in the southeast Pacific (SEP; Fig. 2a) from December 2003 to May 2007 by the Peruvian non-governmental organization Pro Delphinus (Alfaro Shigueto et al. 2008). Turtle data in the northeast Atlantic (NEA; Fig. 2b) were collected from September to October 2002 and August to November 2003 during an experimental fishery project in the Azores (Bolten et al. 2004). Skin samples of 26 and 53 turtles from the SEP and NEA, respectively, were collected from the dorsal surface of the neck using a razor blade (SEP) or $6 \mathrm{~mm}$ biopsy punch (NEA). We used skin tissues because they reflect dietary signatures over an intermediate time frame of approximately $46 \mathrm{~d}$ in juvenile loggerheads (Reich et al. 2008). Samples were preserved in dry $\mathrm{NaCl}$ (SEP) or $70 \%$ EtOH (NEA); neither preservative affects isotope signatures (Barrow et al. 2008, J. A. Seminoff \& L. E. Hess unpubl. data). For each loggerhead, we recorded geographic location (latitude and longitude), date of capture, and curved carapace length (CCL) from the nuchal notch to the posterior-most tip (SEP) or to the posterior marginal notch (NEA) (Bolten 1999). All turtles were released with Inconel identification tags applied to the trailing edge of each fore flipper.

In the SEP, tissue samples from other food-web organisms ( 3 species of fish and 1 species of squid; see Table 1 for scientific names) were collected for analysis during December 2008 with $6 \mathrm{~mm}$ biopsy punches. To characterize isotopically the base of the food web in the SEP, POM samples were also collected off southern Peru in December 2008 by filtration of 4 to 81 of surface seawater through pre-combusted $\left(500^{\circ} \mathrm{C}, 5 \mathrm{~h}\right)$ Millipore quartz fiber filters. Food-web organisms and POM were stored frozen until dried at $60^{\circ} \mathrm{C}$ prior to sample preparation and analysis. In the NEA, red algae, crabs, and barnacles (see Table 1 for scientific names) were gently removed from the carapace of the turtles sampled and preserved in $70 \%$ ethanol as examples from the region of different trophic-level
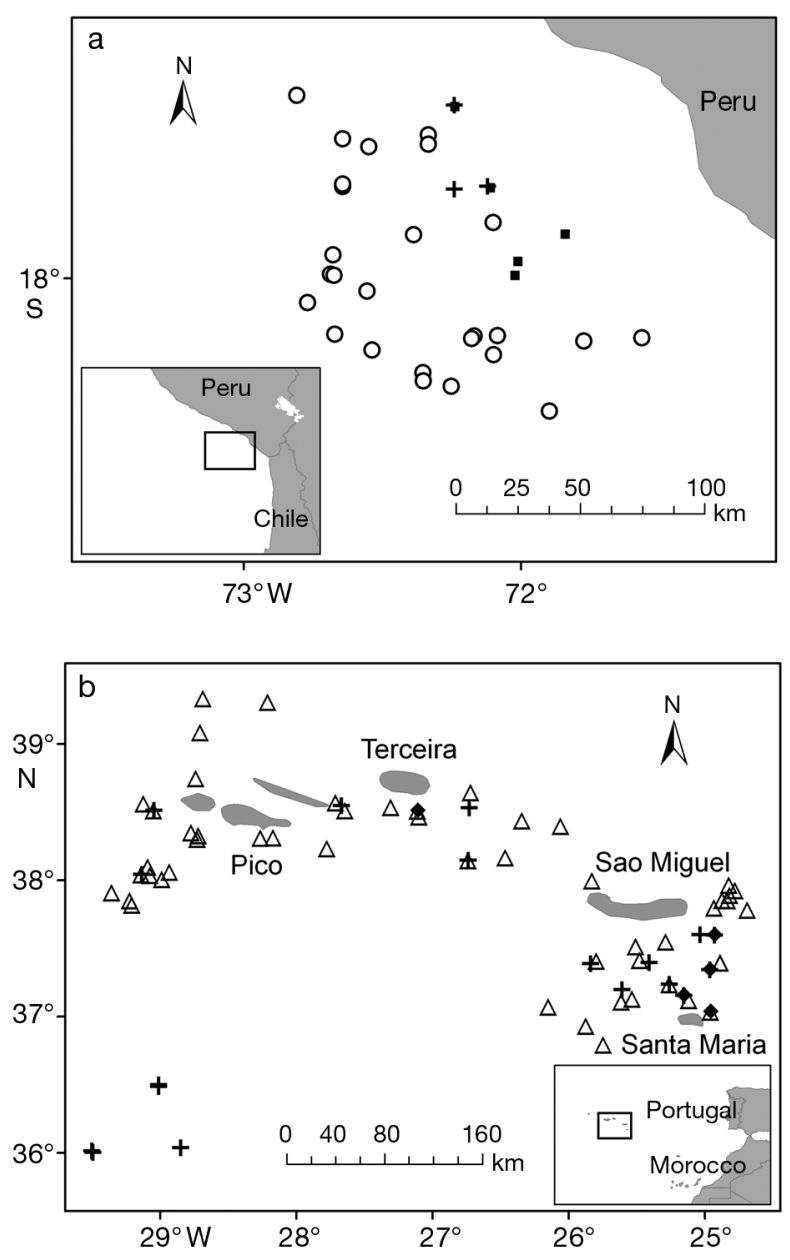

Fig. 2. Caretta caretta. Collection sites of loggerhead turtle skin samples off southern Peru in the southeast Pacific $(a ; O)$ and in Azorean waters in the northeast Atlantic $(b ; \Delta)$. Particulate organic matter $\left(a_{i} \boldsymbol{\square}\right)$, red algae $\left(b_{i} \bullet\right)$, and other foodweb organisms $\left(a\right.$ and $b_{;}+$) collected are also shown

organisms. Zooplankton samples were collected during September 2008 by oblique hauling bongo-nets (mesh size $200 \mu \mathrm{m}$ ) at $50 \mathrm{~m}$ depth, frozen, and then dried at $60^{\circ} \mathrm{C}$ before analysis.

Sample preparation and analysis. Turtle skin samples were washed with deionized water and alcohol swabs to remove epibionts and extraneous particles. The outermost layer of the turtle epidermis was separated from the underlying tissue and finely diced with a scalpel blade. Muscle tissue from fish and squid was washed in deionized water and homogenized. For crabs, muscle tissue was obtained from abdominal segments, and for barnacles, whole organisms (not including the shells) were analyzed. Barnacle tissues were soaked in $1 \mathrm{~N} \mathrm{HCl}$ to remove carbonates. Red algae samples were rinsed with deionized water and small 
invertebrates were removed. All turtle skin, fish, squid, crab, barnacle, algae, and zooplankton samples were dried at $60^{\circ} \mathrm{C}$ for $24 \mathrm{~h}$. Lipids were extracted from turtle, fish, squid, crab, and zooplankton samples using petroleum ether in a Dionex accelerated solvent extractor. All samples, except the finely diced turtle samples, were then ground to a fine powder using a mortar and pestle. POM filter samples were dried at $60^{\circ} \mathrm{C}$ for $24 \mathrm{~h}$, washed with $1 \mathrm{~N} \mathrm{HCl}$ to remove carbonates and dried again for analysis.

For stable-isotope analysis, approximately 500 to $600 \mu \mathrm{g}$ of each sample (1200 to $1500 \mu \mathrm{g}$ for red algae) was weighed and sealed in a tin capsule. POM filters were cut into halves that were also loaded in tin capsules. Samples were analyzed for $\delta^{13} \mathrm{C}$ and $\delta^{15} \mathrm{~N}$ by combustion in a COSTECH ECS 4010 elemental analyzer interfaced via a Finnigan-MAT ConFlow III device to a Finnigan-MAT DeltaPlus XL isotope ratio mass spectrometer in the Stable Isotope Geochemistry Lab at the University of Florida, Gainesville.

Stable-isotope ratios, which compare the ratios of heavy and light isotopes of an element in the sample to an international standard, are reported in the conventional $\delta$ notation:

$$
\delta \mathrm{X}=\left[\left(R_{\text {sample }} / R_{\text {standard }}\right)-1\right] \times 1000
$$

where $\delta \mathrm{X}$ is the relative abundance of ${ }^{13} \mathrm{C}$ or ${ }^{15} \mathrm{~N}$ in the sample expressed in parts per thousand (\%); $R_{\text {sample }}$ and $R_{\text {standard }}$ are the ratios of heavy to light isotope $\left({ }^{13} \mathrm{C} /{ }^{12} \mathrm{C}\right.$ and $\left.{ }^{15} \mathrm{~N} /{ }^{14} \mathrm{~N}\right)$ in the sample and international standard, respectively. The standard used for ${ }^{13} \mathrm{C}$ was Vienna Pee Dee Belemnite and for ${ }^{15} \mathrm{~N}$ was atmospheric $\mathrm{N}_{2}$. Working standards L-glutamic acid USGS40 $\left(\delta^{13} \mathrm{C}=-26.23\right.$ and $\left.\delta^{15} \mathrm{~N}=-4.52\right)$ were calibrated monthly against international standards and were inserted in all runs at regular intervals to calibrate the system. The analytical accuracy of our measurements, measured as the SD of replicates of standards, was $0.20 \%$ for $\delta^{13} \mathrm{C}$ and $0.14 \%$ for $\delta^{15} \mathrm{~N}$ ( $\mathrm{n}=28$ and 28 , respectively).

Statistical analysis. Sea turtle data were tested for normality using the Shapiro-Wilk test. $\delta^{13} \mathrm{C}$ and $\delta^{15} \mathrm{~N}$ in turtle skin samples were compared between ocean basins with Student's $t$-tests. The relationships between stable isotope values and body size were evaluated with linear regressions. The software program $\mathrm{R}$ (www.r-project.org) was used for all analyses with an $\alpha$ level of 0.05 .

\section{RESULTS}

Values of $\delta^{13} \mathrm{C}$ from SEP loggerheads ranged from -14.6 to $-17.4 \%$ (mean $\pm \mathrm{SD}:-16.3 \pm 0.7 \%$ ), and for NEA loggerheads ranged from -15.7 to $-17.8 \%$ $\left(\right.$ mean $\pm \mathrm{SD}:-16.7 \pm 0.5 \%$ ). Values of $\delta^{15} \mathrm{~N}$ ranged from 15.2 to $18.7 \%$ o (mean \pm SD: $17.1 \pm 0.9 \%$ ) in SEP loggerheads and from 6.4 to $8.7 \%$ o (mean \pm SD: $7.6 \pm$ $0.5 \%$ ) in NEA loggerheads. The $\delta^{13} \mathrm{C}$ and $\delta^{15} \mathrm{~N}$ values for loggerheads were normally distributed (ShapiroWilk test, $\mathrm{p}>0.05)$. Although the NEA $\delta^{13} \mathrm{C}$ values were almost completely encompassed by the SEP values (86\% overlap of the data), NEA $\delta^{13} \mathrm{C}$ values were significantly lower than those from the SEP $(t=3.7$, $\mathrm{p}<0.001$; Fig. 3). Also, SEP samples showed significantly higher $\delta^{15} \mathrm{~N}$ values than those from the NEA $(t=59.3, \mathrm{p}<0.001 ;$ Fig. 3).

In the SEP, POM samples had the lowest $\delta^{15} \mathrm{~N}$ and $\delta^{13} \mathrm{C}$ values, while the other organisms ranged above these values (Table 1). Similarly, in the NEA, red algae had the lowest $\delta^{15} \mathrm{~N}$ and $\delta^{13} \mathrm{C}$ values, while the other food-web components had higher values of $\delta^{15} \mathrm{~N}$ and $\delta^{13} \mathrm{C}$ (Table 1). Almost all values of $\delta^{15} \mathrm{~N}$ in the NEA fell below those in the SEP.

Turtles sampled in the SEP were all immature, with CCL ranging from 35.9 to $81.4 \mathrm{~cm}$, which is consistent with the size range previously reported for the region (Alfaro Shigueto et al. 2008). Body size had a significant positive relationship with $\delta^{15} \mathrm{~N}\left(\mathrm{R}^{2}=0.26\right.$, df $=24$, $\mathrm{p}=0.008$; Fig. 4), but not with $\delta^{13} \mathrm{C}(\mathrm{p}=0.354)$. Turtles in the NEA were also all immature and ranged in size from 33.1 to $80.3 \mathrm{~cm}$ CCL. Similar to loggerheads in the SEP, there was a significant positive relationship between body size and $\delta^{15} \mathrm{~N}\left(\mathrm{R}^{2}=0.10\right.$, df $=51, \mathrm{p}=$ 0.023 ; Fig. 4), but not between body size and $\delta^{13} \mathrm{C}(\mathrm{p}=$ $0.110)$.

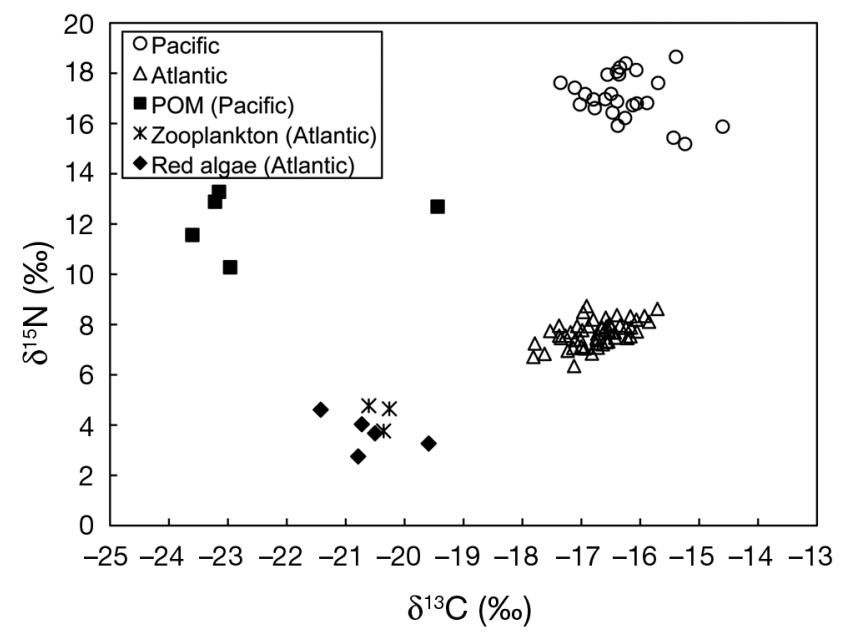

Fig. 3. Caretta caretta. Stable-isotope ratios of nitrogen $\left(\delta^{15} \mathrm{~N}\right)$ and carbon $\left(\delta^{13} \mathrm{C}\right)$ of skin samples from juvenile loggerheads off southern Peru in the southeast Pacific (O) and in Azorean waters in the northeast Atlantic $(\Delta)$. Particulate organic matter (POM) values off southern Peru and red algae and zooplankton samples from Azorean waters are also shown 
Table 1. Stable-isotope ratios of marine organisms in the southeast Pacific and the northeast Atlantic. Values are mean \pm SD. na: not applicable; POM: particulate organic matter

\begin{tabular}{|c|c|c|c|c|}
\hline Species & $\mathrm{n}$ & $\delta^{15} \mathrm{~N}(\%)$ & $\delta^{13} \mathrm{C}(\%)$ & Source \\
\hline \multicolumn{5}{|l|}{ Southeast Pacific } \\
\hline POM & na & $12.1 \pm 1.2$ & $-22.4 \pm 1.7$ & Present study \\
\hline \multicolumn{5}{|l|}{ Mollusca } \\
\hline Jumbo squid Dosidicus gigas & 3 & $18.6 \pm 0.4$ & $-17.6 \pm 0.4$ & Present study \\
\hline \multicolumn{5}{|l|}{ Chondrychthyes } \\
\hline Blue shark Prionace glauca & 1 & 18.2 & -16.4 & Present study \\
\hline \multicolumn{5}{|l|}{ Osteichthyes } \\
\hline Anchovy Engraulis ringens & 2 & $14.2 \pm 0.9$ & $-16.7 \pm 0.1$ & Catenazzi \& Donnelly (2008) \\
\hline Mahi mahi Coryphaena hippurus & 2 & $14.9 \pm 1.6$ & $-16.5 \pm 0.1$ & Present study \\
\hline Flying fish Exocoetus sp. & 3 & $16.9 \pm 0.9$ & $-18.0 \pm 0.2$ & Present study \\
\hline Chub mackerel Scomber japonicus & 2 & $15.8 \pm 1.4$ & $-17.0 \pm 0.8$ & Present study \\
\hline \multicolumn{5}{|l|}{ Reptilia } \\
\hline Loggerhead turtle Caretta caretta & 26 & $17.1 \pm 0.9$ & $-16.3 \pm 0.7$ & Present study \\
\hline Leatherback turtle Dermochelys coriacea & 37 & $15.4 \pm 1.8$ & $-19.1 \pm 0.7$ & Wallace et al. (2006) \\
\hline \multicolumn{5}{|l|}{ Mammalia } \\
\hline Sea lion Otaria flavescens & 6 & $17.4 \pm 0.9$ & $-15.1 \pm 0.4$ & Catenazzi \& Donnelly (2008) \\
\hline Sperm whale Physeter macrocephalus & 12 & 18.6 to 20.3 & -16.0 to -14.7 & Marcoux et al. (2007) \\
\hline \multicolumn{5}{|l|}{ Northeast Atlantic } \\
\hline Red algae Polysiphonia sp. & 5 & $3.7 \pm 0.7$ & $-20.6 \pm 0.7$ & Present study \\
\hline Zooplankton & 3 & $4.4 \pm 0.6$ & $-20.4 \pm 0.2$ & Present study \\
\hline \multicolumn{5}{|l|}{ Crustacea } \\
\hline Acorn barnacle Chelonibia sp. & 3 & $7.6 \pm 0.1$ & $-19.0 \pm 0.6$ & Present study \\
\hline Gooseneck barnacle Lepas anatifera & 4 & $5.7 \pm 1.6$ & $-20.0 \pm 0.5$ & Present study \\
\hline Pedunculate barnacle Conchoderma virgatum & 3 & $5.7 \pm 0.7$ & $-19.1 \pm 0.6$ & Present study \\
\hline Columbus crab Planes minutus & 5 & $9.0 \pm 0.6$ & $-18.4 \pm 0.5$ & Present study \\
\hline \multicolumn{5}{|l|}{ Reptilia } \\
\hline Loggerhead turtle Caretta caretta & 53 & $7.6 \pm 0.5$ & $-16.7 \pm 0.5$ & Present study \\
\hline \multirow[t]{3}{*}{ Leatherback turtle Dermochelys coriacea } & 67 & $9.8 \pm 1.5^{\mathrm{a}}$ & $-19.4 \pm 1.0^{\mathrm{a}}$ & Wallace et al. (2006) \\
\hline & 4 & $10.4 \pm 0.1^{\mathrm{b}}$ & $-22.6 \pm 0.6^{\mathrm{b}}$ & Maros et al. (2006) \\
\hline & 63 & $9.5 \pm 0.2^{\mathrm{b}}$ & $-18.8 \pm 0.1^{b}$ & Caut et al. (2008) \\
\hline \multicolumn{5}{|l|}{ Aves } \\
\hline Cory's shearwater Calonectris diomedea borealis & 35 & 13.2 & -16.2 & Ramos et al. (2009) \\
\hline \multicolumn{5}{|l|}{ Mammalia } \\
\hline Sperm whale Physeter macrocephalus & 1 & 13.2 & -11.8 & Mendes et al. (2007) \\
\hline
\end{tabular}

\section{DISCUSSION}

\section{Differences between ocean basins}

We would expect similar $\delta^{13} \mathrm{C}$ in both SEP and NEA loggerhead populations, reflecting their oceanic feeding behavior. Based on satellite telemetry studies, juvenile loggerheads in the NEA feed in oceanic, epipelagic zones (Santos et al. 2008), and all loggerheads, both in the NEA and SEP, in the present study were captured in the oceanic zone (Bolten et al. 2004, Alfaro Shigueto et al. 2008). However, NEA $\delta^{13} \mathrm{C}$ values were significantly lower than in SEP loggerheads, although carbon value ranges for both populations greatly overlapped $(86 \%)$, confirming their oceanic and pelagic feeding strategy (Fig. 3). The lower $\delta^{13} \mathrm{C}$ in
NEA loggerheads is unlikely to result from the latitudinal gradient in marine-phytoplankton $\delta^{13} \mathrm{C}$, which decreases from the equatorial zones toward the polar regions (Rau et al. 1982). Because this decline is more pronounced in the southern hemisphere $(-0.14$ and $-0.015 \%$ per degree in the southern and northern hemispheres, respectively, Rau et al. 1982), SEP loggerheads should have lower $\delta^{13} \mathrm{C}$ than NEA loggerheads, the opposite of the pattern we found.

Visual inspection of Fig. 5 reveals a general trend for NEA organisms to have lower $\delta^{13} \mathrm{C}$ than SEP organisms. Thus, NEA POM may well have lower $\delta^{13} \mathrm{C}$ values than SEP POM, which would be transferred up the trophic levels to loggerheads. We used red algae in the NEA as a proxy for a baseline isotopic signature in Azorean waters for $\delta^{15} \mathrm{~N}$, but red algae should have 


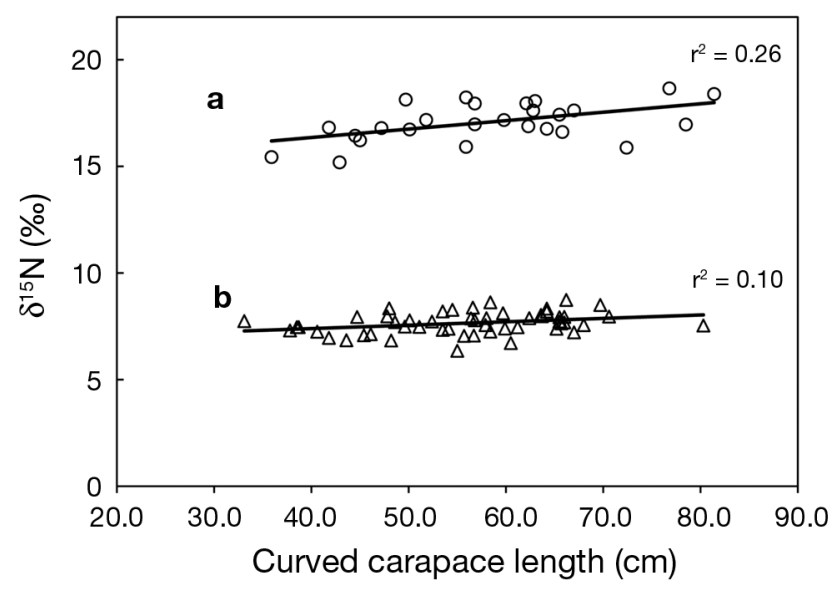

Fig. 4. Caretta caretta. Skin $\delta^{15} \mathrm{~N}$ vs. curved carapace length in loggerhead sea turtles off (a) southern Peru in the southeast Pacific and (b) the Azores in the northeast Atlantic. Both relationships are significant (see 'Results')

higher $\delta^{13} \mathrm{C}$ than phytoplankton or POM. The thinner diffusive boundary layers adjacent to the external environment in phytoplankton compared to those in macroalgae facilitate the discrimination of heavy isotopes $\left({ }^{13} \mathrm{C}\right)$, resulting in more depleted $\delta^{13} \mathrm{C}$ signatures for phytoplankton (France 1995).

The mean $\delta^{15} \mathrm{~N}$ value in SEP loggerheads was 9.4\% higher than in NEA loggerheads (Fig. 3). Large differences in the nitrogen signature of organisms suggest differences in trophic levels, but the relative trophic positions of loggerhead populations in the SEP and NEA appear to be similar. The difference in mean $\delta^{15} \mathrm{~N}$ values between primary producers (POM and red algae) and loggerheads was 4.9 and $4.0 \%$ in the SEP and NEA, respectively. The slightly smaller difference in the NEA probably reflects the fact that, unlike POM, red algae are not the base of the food web in the open ocean. We expected that NEA POM values of $\delta^{15} \mathrm{~N}$ would be lower than those of red algae, yielding a value $>4.0 \%$ and more similar to $4.9 \%$. This is because phytoplankton discriminate against the heavy nitrogen isotope $\left({ }^{15} \mathrm{~N}\right)$ more strongly than macrophytes (Montoya \& McCarthy 1995, De Brabandere et al. 2007). Hence, we attribute the $\delta^{15} \mathrm{~N}$ difference between loggerhead populations to different $\delta^{15} \mathrm{~N}$ values at the base of the food chain. These results emphasize the need for knowledge of community $\delta^{15} \mathrm{~N}$ baseline signatures when identifying trophic levels or when comparing organisms between communities.

Recently, Bourbonnais et al. (2009) found support for $\mathrm{N}_{2}$ fixation in the Azores Front region, reporting low values of $\delta^{15} \mathrm{~N}$ for dissolved organic nitrogen. Because discrimination against ${ }^{15} \mathrm{~N}$ during $\mathrm{N}_{2}$ fixation is small, newly fixed nitrogen has a $\delta^{15} \mathrm{~N}$ signature similar to that of atmospheric $\mathrm{N}$, near $0 \%$ (Minagawa \& Wada 1986). Ultimately, food-web base organisms whose nitrogen input comes from $\mathrm{N}_{2}$ fixation will show depleted $\delta^{15} \mathrm{~N}$ values (Montoya et al. 2002). The low $\delta^{15} \mathrm{~N}$ values reported in the present study for red algae and zooplankton (Fig. 3) are thus consistent with the presence of $\mathrm{N}_{2}$ fixation in our study area.

On the other hand, the SEP is characterized by a shallow oxygen-depleted water layer off Peru where high rates of denitrification occur (Codispoti et al. 2001), including autotrophic denitrification (Ward et al. 2009). As nitrate is consumed during denitrification, lighter isotopes of nitrogen are preferentially utilized, leaving residual nitrate pools heavily enriched in ${ }^{15} \mathrm{~N}$. The resultant high $\delta^{15} \mathrm{~N}$ in the subsurface denitrification layer is transmitted to surface waters through upwelling (Saino \& Hattori 1987). The constant supply of ${ }^{15} \mathrm{~N}$-enriched nitrates in the surface ocean are later assimilated by phytoplankton (Fig. 1b), which in turn show high $\delta^{15} \mathrm{~N}$ signatures, as reflected in our POM samples (Fig. 3).

A novel analysis by Deutsch et al. (2007) reports that the highest rates of $\mathrm{N}_{2}$ fixation are geographically coupled with that of denitrification, suggesting that the highest rates of $\mathrm{N}_{2}$ fixation could be found proximal to the eastern tropical Pacific (ETP; where highest rates of denitrification occur) and not in the tropical North

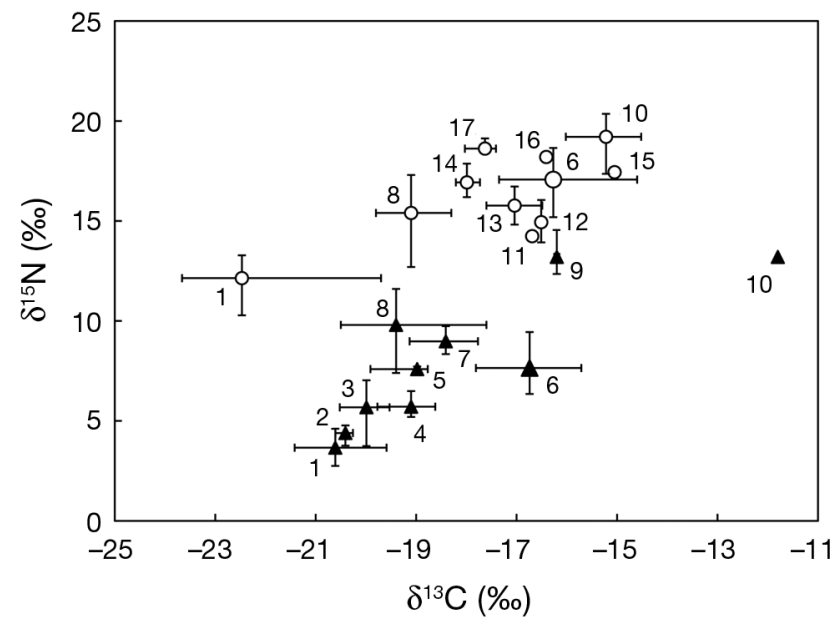

Fig. 5. Comparison of stable-isotope ratios $\left(\delta^{13} \mathrm{C}\right.$ and $\left.\delta^{15} \mathrm{~N}\right)$ of the food-web components in the southeast Pacific (SEP; O) and the northeast Atlantic $\left(\mathrm{NEA}_{i} \mathbf{\Delta}\right)$. All SEP values are from waters off Peru except for those of leatherback sea turtles. In the NEA, all values are from waters off the Azores except for those of leatherback sea turtles. Leatherback isotopic values are from Wallace et al. (2006). All values are mean \pm range. 1: POM (SEP) or red algae (NEA); 2: zooplankton; 3: gooseneck barnacle; 4 : pedunculate barnacle; 5 : acorn barnacle; 6 : loggerhead turtle; 7: Columbus crab; 8: leatherback turtle; 9: Cory's shearwater; 10: sperm whale; 11: anchovy; 12: mahi mahi; 13: chub mackerel; 14: flying fish; 15: sea lion; 16: blue shark; 17: jumbo squid. For scientific names, sample sizes, and references see Table 1 
Atlantic as previously thought. It is not certain if, at a much finer scale, areas of nitrogen fixation overlap with those of denitrification. However, $\mathrm{N}_{2}$ fixation lowers $\delta^{15} \mathrm{~N}$ values of nitrates by about $2 \%$, while denitrification increases values by about 10\% (Montoya 2007). The high values of $\delta^{15} \mathrm{~N}$ in our POM samples reflect the high rates of denitrification in the ETP even if $\mathrm{N}_{2}$ fixation were occurring because of the overwhelming effect of denitrification on the $\delta^{15} \mathrm{~N}$.

Environmental forces acting on resource availability drive variations in the life history of conspecifics as suggested by data compiled on species across a wide range of trophic levels in several oceanic regions (Suryan et al. 2009). Adult leatherback turtles exhibit variation in size and reproductive output as a response of different regional environmental forcing (as reviewed by Suryan et al. 2009). To what extent the differences in energy flow in our study areas (through prevalence of $\mathrm{N}_{2}$ fixation in one and denitrification in the other), along with other climatic factors affecting nutrient availability (e.g. El Niño events), may shape the biology of the juvenile loggerhead populations is still poorly understood.

\section{Food-web isotopic structure}

Isotopic signatures in the food web of the SEP show that high nitrogen baseline values - driven by denitrification-are conserved through several trophic levels. A similar pattern is observed in the NEA, where low $\delta^{15} \mathrm{~N}$ in red algae and especially zooplanktondue to $\mathrm{N}_{2}$ fixation - give the food web overall low $\delta^{15} \mathrm{~N}$ values when compared to the isotopic values in the SEP food web (Fig. 5).

Organisms analyzed in the present study, as well as the collection of published signatures of organisms off southern Peru and the Azores, allow for a first insight into the isotopic composition of the food-web structure off the SEP and the NEA. In the SEP, the average $\delta^{15} \mathrm{~N}$ signature of the anchovy Engraulis ringens is low, reflecting its diet preference for large zooplankton (Espinoza \& Bertrand 2008). The $\delta^{15} \mathrm{~N}$ increases in larger fishes such as mackerel Scomber japonicus and flying fish Exocoetus spp. Also as expected, higher trophic-level species such as sea lion Otaria flavescens, sperm whale Physeter macrocephalus, blue shark Prionace glauca, and jumbo squid Dosidicus gigas show much higher $\delta^{15} \mathrm{~N}$ signatures (Fig. 5). A similar pattern is observed in the Azores, where nitrogen signatures in filter-feeding organisms such as pedunculate barnacles (Conchoderma virgatum and Lepas anatifera) show higher values than those from zooplankton but lower than those from crabs or loggerhead turtles. Highest $\delta^{15} \mathrm{~N}$ values are reported from sperm whale and Cory's shearwater Calonectris diomedea borealis, which reflect their diet preference for mainly cephalopods and fish, respectively (Clarke et al. 1993, Granadeiro et al. 1998).

The difference in $\delta^{15} \mathrm{~N}$ signatures between Pacific and Atlantic loggerheads found in the present study was higher than that reported by Wallace et al. (2006) between leatherbacks in the same ocean basins $(9.5 \%$ and $5.6 \%$ for loggerheads and leatherbacks, respectively; Fig. 5). The specialist feeding behavior of leatherbacks on jellyfish and the generalist feeding strategy of loggerheads, with known intermediate and higher trophic status respectively, allows the comparison of nitrogen signatures between these 2 species. However, we cannot make direct comparisons between leatherbacks and loggerheads because leatherbacks were sampled on tropical nesting beaches and the foraging areas of the sampled leatherbacks are not known.

\section{Relationship between $\delta^{15} \mathrm{~N}$ and turtle size}

The increase of loggerhead $\delta^{15} \mathrm{~N}$ with size may result from (1) growth rate, (2) gape size, and/or (3) mesopelagic prey. Rapidly growing smaller juveniles may show a lower nitrogen discrimination value than larger juveniles with slower growth rates (Martínez del Rio \& Wolf 2005, Reich et al. 2008). This translates to lower $\delta^{15} \mathrm{~N}$ values in smaller juveniles even if they are feeding on the same diet as larger juveniles. Larger gape size in larger turtles could allow them to ingest larger prey in higher trophic levels, resulting in higher $\delta^{15} \mathrm{~N}$ in larger turtles.

The third possible explanation for the higher $\delta^{15} \mathrm{~N}$ in larger turtles is that larger turtles may consume more mesopelagic organisms with enriched $\delta^{15} \mathrm{~N}$ values. Because POM $\delta^{15} \mathrm{~N}$ increases with depth (Saino \& Hattori 1987, Montoya et al. 2002), feeding on mesopelagic prey would increase the $\delta^{15} \mathrm{~N}$ in turtles compared to those with an epipelagic feeding behavior. Increasing diving capacity (dive duration and depth) with body size is well known in many air-breathing organisms (Schreer \& Kovacs 1997) and has also been observed in juvenile sea turtles (Salmon et al. 2004 and references therein). Mesopelagic prey items have been found in stomach contents in oceanic loggerheads in the central North Pacific (Parker et al. 2005), and satellite telemetry has shown that oceanic loggerheads can dive and probably forage in up to $100 \mathrm{~m}$ depth (Polovina et al. 2003). Compound-specific nitrogen isotope analysis of loggerhead tissues could help elucidate whether the differences in $\delta^{15} \mathrm{~N}$ are due to metabolic and trophiclevel relationships or changes in isotopic composition at the base of the food web without the necessity of food-web base sampling (Popp et al. 2007). 


\section{CONCLUSIONS}

In the present study, loggerhead turtles revealed the ocean basin differences in $\delta^{15} \mathrm{~N}$ that were also found in leatherback turtles. The variation in the $\delta^{15} \mathrm{~N}$ at the base of the food web and other organisms within the SEP and NEA demonstrates that this difference in the baseline nitrogen signature is conserved through higher trophic levels, thus reflecting characteristics of the nitrogen cycling regime in each ocean basin. The $\delta^{13} \mathrm{C}$ and $\delta^{15} \mathrm{~N}$ values in higher trophic-level organisms, such as sea turtles, may help elucidate changing oceanographic conditions, but systematic and long-term sampling is needed. Additional compound-specific isotopic analyses may explain variations in nitrogen source and hence help reveal changing oceanographic conditions.

Acknowledgements. We thank C. Caceres, F. Bernedo, M. Mamani, and D. Vega for their invaluable support during fieldwork in Peru. We also thank 'Equipa Tartaruga' and P. Lambardi (University of the Azores, Department of Oceanography and Fisheries) for turtle sample and zooplankton collection in the Azores, respectively. Azores samples were collected with funds from the US National Marine Fisheries Service (2002: NA16FM2589, 2003: NA03NMF4540204) to A.B.B. and K.A.B. Samples from Peru were collected with funding support from the Southwest Fisheries Science Center of the National Oceanographic and Atmospheric Administration, the National Fish and Wildlife Foundation, and the Oregon Zoo Conservation Fund. The Stable Isotope Lab at the University of Florida and J. Curtis are acknowledged for assistance with stable-isotope analyses. Funding for this project was provided by Lerner-Gray Grants for Marine Research (American Museum of Natural History) and Brian Riewald Memorial Fund (University of Florida). M.P. was supported by a Fulbright Scholarship (Peru) and Dexter Fellowship in Tropical Conservation Biology (University of Florida). Turtle samples were collected following national regulations. The Peruvian Instituto Nacional de Recursos Naturales (INRENA) and the Fisheries Board of the Azores government (DRP-SRAP) provided research and sample collection permits. All samples were transported to the Department of Zoology, University of Florida (Gainesville) under CITES export/import permits for analysis. Methodologies were approved by the Institutional Animal Care and Use Committee, University of Florida.

\section{LITERATURE CITED}

Alfaro Shigueto J, Mangel JC, Seminoff JA, Dutton PH (2008) Demography of loggerhead turtles Caretta caretta in the southeastern Pacific Ocean: fisheries-based observations and implications for management. Endang Species Res 5: 129-135

Barrow L, Bjorndal K, Reich K (2008) Effects of preservation method on stable carbon and nitrogen isotope values. Physiol Biochem Zool 81:688-693

Bjorndal KA (1997) Foraging ecology and nutrition of sea turtles. In: Lutz PL, Musick JA (eds) The biology of sea turtles. CRC Press, Boca Raton, FL, p 199-222

Bolten AB (1999) Techniques for measuring sea turtles. In: Eckert KL, Bjorndal KA, Abreu-Grobois FA, Donnelly M (eds) Research and management techniques for the conservation of sea turtles. IUCN/SSC Marine Turtle Specialist Group Publ No. 4, Washington, DC, p 126-132

Bolten AB, Martins HR, Isidro E, Santos M and others (2004) Experiment to evaluate gear modification on rates of sea turtle bycatch in the swordfish longline fishery in the Azores-Phase 1 and Phase 2. In: Long KJ, Schroeder BA (eds) Proc Int Tech Expert Workshop Marine Turtle Bycatch in Longline Fisheries, Seattle, WA, 11-13 Feb 2003. NOAA Tech Memo NMFS-OPR-26. NOAA, National Marine Fisheries Service, Silver Spring, MD, p 139-153. Available at: www.nmfs.noaa.gov/pr/pdfs/interactions/turtle_bycatch_ workshop.pdf

Bourbonnais A, Lehmann MF, Waniek JJ, Schulz-Bull DE (2009) Nitrate isotope anomalies reflect $\mathrm{N}_{2}$ fixation in the Azores Front region (subtropical NE Atlantic). J Geophys Res 114:C03003, doi: 10.1029/2007JC004617

Carpenter EJ, Harvey HR, Fry B, Capone DG (1997) Biogeochemical tracers of the marine cyanobacterium Trichodesmium. Deep-Sea Res I 44:27-38

> Catenazzi A, Donnelly M (2008) Sea lion Otaria flavescens as host of the common vampire bat Desmodus rotundus. Mar Ecol Prog Ser 360:285-289

Caut S, Fossette S, Guirlet E, Angulo E, Das K, Girondot M, Georges JY (2008) Isotope analysis reveals foraging area dichotomy for Atlantic leatherback turtles. PLoS ONE 3(3): e1845

Clarke MR, Martins HR, Pascoe P (1993) The diet of sperm whales (Physeter macrocephalus Linnaeus 1758) off the Azores. Philos Trans R Soc Lond B 339:67-82

Codispoti LA, Brandes JA, Christensen JP, Devol AH, Naqvi SWA, Paerl HW, Yoshinari T (2001) The oceanic fixed nitrogen and nitrous oxide budgets: moving targets as we enter the anthropocene? Sci Mar 65:85-105

De Brabandere L, Frazer TK, Montoya J (2007) Stable nitrogen isotope ratios of macrophytes and associated periphyton along a nitrate gradient in two subtropical, spring-fed streams. Freshw Biol 52:1564-1575

> DeNiro MJ, Epstein S (1978) Influence of diet on the distribution of carbon isotopes in animals. Geochim Cosmochim Acta 42:495-506

DeNiro MJ, Epstein S (1981) Influence of diet on the distribution of nitrogen isotopes in animals. Geochim Cosmochim Acta 45:341-351

> Deutsch C, Sarmiento JL, Sigman DM, Gruber N, Dunner JP (2007) Spatial coupling of nitrogen inputs and losses in the ocean. Nature 445:163-167

- Espinoza P, Bertrand A (2008) Revisiting Peruvian anchovy (Engraulis ringens) trophodynamics provides a new vision of the Humboldt Current system. Prog Oceanogr 79: $215-227$

- France RL (1995) Carbon-13 enrichment in benthic compared to planktonic algae: foodweb implications. Mar Ecol Prog Ser 124:307-312

Frick MG, Williams KL, Bolten AB, Bjorndal KA, Martins HR (2009) Foraging ecology of oceanic-stage loggerhead turtles Caretta caretta. Endang Species Res 9:91-97

Granadeiro JP, Monteiro LR, Furness RW (1998) Diet and feeding ecology of Cory's shearwater Calonectris dimomedea in the Azores, north-east Atlantic. Mar Ecol Prog Ser 166:267-276

> Gruber N, Sarmiento N (1997) Global patterns of marine nitrogen fixation and denitrification. Global Biogeochem Cycles 11:235-266

Hatase H, Takai N, Matsuzawa Y, Sakamoto W and others (2002) Size-related differences in feeding habitat use of adult female loggerhead turtles Caretta caretta around 
Japan determined by stable isotope analyses and satellite telemetry. Mar Ecol Prog Ser 233:273-281

Hobson KA, Piatt JF, Pitocchelli J (1994) Using stable isotope to determine seabird trophic relationships. J Anim Ecol 63: 786-789

Ishibashi H, Díaz-Fernández R, Carrillo E, Koike H (2000) $\delta^{15} \mathrm{~N}$ and $\delta^{13} \mathrm{C}$ measurements from the hawksbill turtle, Eretmochelys imbricata, used for scute sourcing. Bull Grad Sch Social Cultural Stud Kyushu Univ 6:37-45

> Liu K, Su M, Hsueh C, Gong G (1996) The nitrogen isotopic composition of nitrate in the Kuroshio Water northeast of Taiwan: evidence for nitrogen fixation as a source of isotopically light nitrate. Mar Chem 54:273-292

> Marcoux M, Whitehead H, Rendell L (2007) Sperm whale feeding variation by location, year, social group and clan: evidence from stable isotopes. Mar Ecol Prog Ser 333: 309-314

Maros A, Louveaux A, Lelarge C, Girondot M (2006) Evidence of the exploitation of marine resource by the terrestrial insect Scapteriscus didactylus through stable isotope analyzes of its cuticle. BMC Ecol 6:6

Martínez del Rio C, Wolf BO (2005) Mass balance models for animal isotopic ecology. In: Starck MA, Wang $\mathrm{T}$ (eds) Physiological and ecological adaptations to feeding in vertebrates. Science Publishers, Enfield, NH, p 141-174

Martínez del Rio C, Wolf N, Carleton SA, Gannes LZ (2009) Isotopic ecology ten years after a call for more laboratory experiments. Biol Rev Camb Philos Soc 84:91-111

Mendes S, Newton J, Reid R, Zuur A, Pierce G (2007) Stable carbon and nitrogen isotope ratio profiling of sperm whale teeth reveals ontogenetic movements and trophic ecology. Oecologia 151:605-615

- Minagawa W, Wada E (1984) Stepwise enrichment of ${ }^{15} \mathrm{~N}$ along food chains: further evidence and the relation between $\delta^{15} \mathrm{~N}$ and animal age. Geochim Cosmochim Acta 48:1135-1140

Minagawa M, Wada E (1986) Nitrogen isotope ratios of red tide organisms in the East China Sea: a characterization of biological nitrogen fixation. Mar Chem 19:245-259

Minami H, Ogi H (1997) Determination of migratory dynamics of the sooty shearwater in the Pacific using stable carbon and nitrogen isotope analysis. Mar Ecol Prog Ser 158: 249-256

Montoya JP (2007) Natural abundance of ${ }^{15} \mathrm{~N}$ in the marine environment. In: Michener RH, Lajtha K (eds) Stable isotopes in ecology and environmental science. Wiley-Blackwell Publishing, Malden, MA, p 176-201

> Montoya JP, McCarthy JJ (1995) Isotopic fractionation during nitrate uptake by phytoplankton grown in continuous culture. J Plankton Res 17:439-464

Montoya JP, Carpenter EJ, Capone DG (2002) Nitrogen fixation and nitrogen isotope abundances in zooplankton of the oligotrophic North Atlantic. Limnol Oceanogr 47: 1617-1628

Parker DM, Cooke WJ, Balazs GH (2005) Diet of oceanic loggerhead sea turtles (Caretta caretta) in the central North Pacific. Fish Bull 103:142-152

Polovina J, Howell E, Parker D, Balazs G (2003) Dive-depth distribution of loggerhead (Caretta caretta) and olive ridley (Lepidochelys olivacea) sea turtles in the central North Pacific: Might deep longline sets catch fewer turtles? Fish Bull 101:189-193

Popp BN, Graham BS, Olson RJ, Hannides CCS and others (2007) Insight into the trophic ecology of yellowfin tuna, Thunnus albacares, from compound-specific nitrogen isotope analysis of proteinaceous amino acids. In: Dawson T,
Siegwolf R (eds) Stable isotopes as indicators of ecological change. Terrestrial Ecology Series. Elsevier/Academic, Amsterdam, p 168-184

Post D (2002) Using stable isotopes to estimate trophic position: models, methods, and assumptions. Ecology 83: 703-718

Ramos R, Gonzáles-Solís J, Forero MG, Moreno R, GómezDíaz E, Ruiz X, Hobson KA (2009) The influence of breeding colony and sex on mercury, selenium and lead levels and carbon and nitrogen stable isotope signatures in summer and winter feathers of Calocnectris shearwaters. Oecologia 159:345-354

> Rau GH, Sweeney RE, Kaplan IR (1982) Plankton ${ }^{13} \mathrm{C}:{ }^{12} \mathrm{C}$ ratio changes with latitude: differences between northern and southern oceans. Deep-Sea Res I 29:1035-1039

> Reich KJ, Bjorndal KA, Martínez del Rio C (2008) Effects of growth and tissue type on the kinetics of ${ }^{13} \mathrm{C}$ and ${ }^{15} \mathrm{~N}$ incorporation in a rapidly growing ectotherm. Oecologia 155:651-663

> Rubenstein D, Hobson K (2004) From birds to butterflies: animal movement patterns and stable isotopes. Trends Ecol Evol 19:256-263

Saino R, Hattori A (1987) Geographical variation of the water column distribution of suspended particulate organic nitrogen and its ${ }^{15} \mathrm{~N}$ natural abundance in the Pacific and its marginal seas. Deep-Sea Res I 34:807-827

Salmon M, Jones TT, Horch KW (2004) Ontogeny of diving and feeding behavior in juvenile seaturtles (Dermochelys coriacea) and green seaturtles (Chelonia mydas) in the Florida Current. J Herpetol 38:36-43

Santos M, Bolten AB, Martins HR, Goncalves J, Riewald B, Bjorndal K (2008) Diving behavior and movements of oceanic stage North Atlantic loggerheads. In: Rees AF, Frick M, Panagopoulou A, Williams K (eds) Proc 27th Annu Symp Sea Turtle Biol Conserv. NOAA Tech Memo NMFS-SEFSC-569. NOAA, Southeast Fisheries Science Center, Miami, FL, p 58. Available at: www.sefsc.noaa. gov/PDFdocs/TM_569_Rees_etal_2008_27.pdf

> Schreer JF, Kovacs KM (1997) Allometry of diving capacities in air-breathing vertebrates. Can J Zool 75:339-358

> Suryan RM, Saba VS, Wallace BP, Hatch SA, Frederiksen M, Wanless S (2009) Environmental forcing on life history strategies: evidence for multi-trophic level responses at ocean basin scales. Prog Oceanogr 81:214-222

> Takai N, Onaka S, Ikeda Y, Yatsu A, Kidokoro H, Sakamoto W (2000) Geographical variations in carbon and nitrogen stable isotopes in squid. J Mar Biol Assoc UK 80:675-684

Vander Zanden HB, Bjorndal KA, Reich KJ, Bolten AB (2010) Individual specialists in a generalist population: results from a long-term stable isotope series. Biol Lett 6:711-714

Voss M, Dippner JW, Montoya JP (2001) Nitrogen isotope patterns in the oxygen-deficient waters of the Eastern Tropical North Pacific Ocean. Deep-Sea Res I 48:1905-1921

- Wada E, Hattori A (1976) Natural abundance of ${ }^{15} \mathrm{~N}$ in particulate organic matter in the North Pacific Ocean. Geochim Cosmochim Acta 40:249-251

> Wallace B, Seminoff J, Kilham S, Spotila J, Dutton P (2006) Leatherback turtles as oceanographic indicators: stable isotope analyses reveal a trophic dichotomy between ocean basins. Mar Biol 149:953-960

> Ward BB, Devol AH, Rich JJ, Chang BX and others (2009) Denitrification as the dominant nitrogen loss process in the Arabian Sea. Nature 461:78-81

- Wu J, Calvert SE, Wong CS (1997) Nitrogen isotope variations in the subarctic northeast Pacific: relationships to nitrogen utilization and trophic structure. Deep-Sea Res I 44:287-314 